Northwestern University School of Law Northwestern University School of Law Scholarly Commons

Faculty Working Papers

2010

\title{
The Political Economy of Taxation: A Critical Review of a Classic
}

Nancy Staudt

Northwestern University School of Law, n-staudt@law.northwestern.edu

\section{Repository Citation}

Staudt, Nancy, "The Political Economy of Taxation: A Critical Review of a Classic" (2010). Faculty Working Papers. Paper 53.

http://scholarlycommons.law.northwestern.edu/facultyworkingpapers/53 
Review Essay

\section{The Political Economy of Taxation: A Critical Review \\ of a Classic}

Nancy C. Staudt

Henry C. Simons, Personal Income Taxation: The Definition of Income as a Problem in Fiscal Policy. Chicago: University of Chicago Press, 1938. $\mathrm{x}+238$ pp.

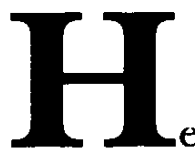

enry Simons's 1938 book, Personal Income Taxation: The Definition of Income as a Problem in Fiscal Policy, is a classic in tax policy circles. Nearly every textbook and scholarly article examining income in the tax context begins with a citation to Simons's pathbreaking work. Simons is widely known as the economist who devised a useful and comprehensive definition of income for income tax purposes. In writing Personal Income Taxation, however, Simons sought to do much more than simply expand the boundaries of taxable income; he hoped Congress would use his work to affect change in the distribution of income between the rich and the poor.

While Simons's definition of income has become classic, his innovative theory regarding the redistribution of wealth has failed to gain support in tax policy circles. The underlying reason for this rejection can be traced to the historical development of tax policy. For over a century prior to the time Simons wrote, tax theorists had maintained a deep commitment to using the tax structure as an instrument to promote economic growth. This concern for market growth and productivity can be seen in the earliest federal tax provisions and in the tax debates throughout the 19th and early 20th centuries. Indeed, by the time Simons wrote in 1938, the market-oriented approach to tax policy had gained such widespread support that distributional fairness

I am grateful to Jim Ely, Nancy King, Bob Rasmussen, and Nancy Reichman for the helpful comments they provided on an early draft of this essay. Address correspondence to Nancy Staudt, Law School, State University of New York at Buffalo, O'Brian Hall, North Campus, Buffalo, NY 14260-1100. 
seemed to be of only secondary importance in tax policy discussions. Simons, in contrast, argued that theorists overstated the benefits of market growth and focused on mitigating income inequality through tax reform. Consequently, legislatures and tax scholars, while applauding his definition of income, have rejected his proposals to redistribute income through tax reform.

Despite Simons's theoretical rejection of the importance of the market for tax policy, like most theorists before him, he could not move beyond the market/nonmarket dichotomy that tends to privilege efficiency over fairness and reproduces the very inequities that disturbed him. Indeed, Simons's classic definition of the term income incorporates the traditional assumptions about the value of market productivity and disregards the importance of nonmarket activities. In this essay I argue that the prevalence of a market-oriented theory in the development of tax policy has had an important effect on the character of our society. Those citizens who participate and successfully invest in the market are perceived as undertaking valuable and productive activities, while those who are less successful or who operate outside the market are seen as unproductive and even lazy. This market/ nonmarket dichotomy has worked to the particular disadvantage of women and people of color who are found in low-income positions and often spend a significant amount of time outside the formal market economy.

\section{Henry Simons's Famous Contribution to the Tax Policy Debates: A Focus on Income Equality}

Although Henry Simons was an economist committed to free trade principles, he found the tax theorists' focus on the market unfortunate. Simons took the position that tax policy should be driven by concerns for economic equality not economic growth ${ }^{1}$ and argued that Congress should use the tax laws to mitigate income disparity between the classes. Acknowledging that he could not prove the importance of fairness, Simons argued that his claim for the redistribution of wealth was ultimately tied to ethics and aesthetic judgment. He noted:

Taxation must affect the distribution of income, whether we will it so or not; and it is only sensible to face the question as to what kinds of effects are desirable. To do this is to reduce the discussion frankly to the level of ethics of aesthetics. ... The case for drastic progression in taxation must be rested on the case against inequality - on the ethical or aesthetic judgment that the prevailing distribution of wealth and income reveals a

1 At the time of publication, Simons's work was both applauded and criticized. The scholarly reviews generally acclaimed Personal Income Taxation as "an invigorating discussion of taxation policy, with lucidly argued proposals" but largely impractical. New York University Law Quarterly Review 1938; see also Cohen 1939; Griswold 1938. 
degree (and/or kind) of inequality which is distinctly evil or him. (Pp. 18-19)

Taking the position that moderation of income inequality was an important objective and that the tax structure was the only proper device for effecting the goal, Simons went on to examine the income tax law as it stood in 1938.

Simons began his tract by noting that despite the existence of the income tax, political and economic theorists had not devised a working definition of the term income. Accordingly, he set out to devise a definition of income for tax purposes. He argued that personal income connotes the exercise of control over the use of society's scarce resources and thus must be tied to consumption and accumulation of savings and property rights. According to Simons, the calculation of income requires an estimate of (1) the amount by which the value of a person's store of property rights increases and (2) the value of rights exercised in consumption (p. 49). In other words, Simons argued that a comprehensive definition of income would include the value of savings and consumed items regardless of whether they were connected to the market.

The definition Simons devised was an important advance in tax theory. Previous theorists had argued that a taxpayer's activity could provide economic gain as well as pleasure not associated with material resources. Simons acknowledged that many activities provide much more than monetary gain but took the position that psychic benefits could not easily or fairly be valued and thus should be ignored for tax policy purposes. Simons intended his definition of income to serve simply as a starting point for determining the extent of the taxpayer's income. His definition continues to serve that important purpose today. ${ }^{2}$ (See Staudt 1996; Klein \& Bankman 1994; Witte 1985; McIntyre \& Oldman 1977.)

Simons, however, did not intend his definition of income to define the contours of the tax code. He argued that once tax theorists identify the extent of income, they must then consider important public policy goals. Simons's purpose was to limit income inequality, and thus he adjusted his definition to serve that goal. His analysis of housework and home ownership illustrates his argument. Simons considered both housework and the benefits of property ownership as producing nonmarket income under his definition, although neither was taxed. Women's housework provides an economic benefit because the family avoids purchasing the services on the market. Property ownership also provides valuable income to the family. If the family did not live in their home, for example, but rented it to a third party,

2 Simons's broad definition of income is also reflected in sec. 61 of the Tax Code and the treasury regulations that call for taxation of all economic gains in whatever form received. 
the rental income would be taxed. Yet when the owner lives in the home, Simons noted that Congress failed to treat the value as taxable income. Based on his redistributive goals, Simons argued that Congress should tax home ownership but leave the benefits of housework untaxed (pp. 110-24).

Simons's argument that Congress should tax the imputed income from property ownership was not simply because it fell within his broad definition of income. Rather, he noted that because the wealthy and not the poor own valuable property, excluding the value of such property from taxation would work to the benefit of high-income families. Simons also argued that by excluding such income, Congress made tax evasion attractive and easy. High-income taxpayers, for example, could easily liquidate investment in corporate securities and reinvest in the type of property, such as a home, that Congress leaves out of the tax base. Simons acknowledged that taxing income from property ownership might be cumbersome, but he nevertheless argued the income must be taxed (pp. 112-24)..$^{3}$

Although Simons argued for taxation of the nonmarket income tied to property, he took just the opposite position with regard to labor. Simons argued that the value of labor performed outside of the market for one's own family was income according to his definition but should be left untaxed. This position was based on the assumption that low-income families have a greater amount of household income from self-supplied services than do high-income families. Low-income women, according to Simons, are more likely to do their own household work, while upperincome women are more likely to purchase the services on the market. Leaving untaxed the income that could be imputed to the family from self-provided services, therefore, arguably awards a benefit to low-income taxpayers and increases the degree of progressivity in the tax rates (pp. 110-12).

Although Simons did not seek to leave the value of housework out of the tax base because it was performed outside the market, the effect of his analysis was to cement the boundary between market and nonmarket activities. Indeed, despite his argument that the value obtained simply from holding property should be taxed, tax theorists often view Simons as the authority for the position that nonmarket gains do not provide taxable income. Thus, not only has Simons's proposal for the redistribution of income been rejected, his work has been used to further

3 Simons questioned whether Congress must tax the benefits accruing for the ownership of furniture, automobiles, art collections, and clothing if it imposed a tax on the benefits of home ownership. Simons also noted that valuation problems might arise if the taxpayer purchases an item that does not satisfy its intended use. If the Hoover cleaner does not vacuum, for example, should Congress impose a tax on the imputed income for the vacuum cleaner? Despite these administrative difficulties, Simons took the position that Congress should tax the benefits of property ownership in an effort to further income equality. 
establish the importance of the market boundary in tax policy and to maintain the very inequities he sought to correct. To understand this unexpected use of Simons's work, it is important to understand the historical development of taxation.

\section{Early Taxation Theory: Putting Simons and His Classic Work into Context}

The road to taxing income was filled with twists and turns as the federal government sought to promote the competing goals of market growth and tax fairness. Throughout the 19th century, citizens remained suspicious of the government's power to tax, yet at the same time, taxation was viewed as an important instrument for ensuring the development of industry and economic prosperity. As Congress struggled to balance these important concerns, each new development in tax policy had the effect of further cementing the boundaries between market and nonmarket behavior.

The first federal tax Congress adopted was a tariff in 1789 . The tariff was intended both to raise revenue for public goods and to protect the American manufacturing industry from cheap European labor. Most commentators viewed the tariff as a tax on foreign manufacturers that would raise the price of imported goods. The tax, therefore, was an external tax that would give local manufacturers a competitive edge in the U.S. market and thus encourage economic growth (Ratner 1967).

Although an important aspect of the tariff was raising revenue for the federal government, ${ }^{4}$ this purpose was often secondary to the goal of regulating trade and promoting economic growth. Indeed, Congress often imposed the tax when it had a surplus of revenue. Accordingly, early tax policy was often driven more by a concern for the market than by the need for revenue. ${ }^{5}$

4 It is important to understand that Congress also used excise (or sales) taxes when the tariffs provided too little revenue. Congress, however, relied on these taxes to a much lesser extent than on the tariff. Despite their relative insignificance, the sales taxes sparked much debate. Many theorists argued the federal legislature could tax foreign goods and services but to impose a tax on locally produced goods was an unlawful exercise of federal power. Accordingly, when Congress implemented the first internal tax on alcohol, the tax was vehemently criticized. The verbal attacks on the law eventually turned violent, erupting into the famous Whisky Rebellion. In response, the federal government called on its military troops to quell the resistance, demonstrating that it was not only willing to adopt the tax on domestic commodities in times of fiscal need but was willing to use force to ensure its collection ( $\mathrm{Hu} \mathrm{1950)}$. In 1812, and in later years, Congress imposed excise taxes on several commodities, including carriages, gasoline, sugar, and luxuries (Ratner 1967). The eventual acceptance of the excise (or sales) tax on domestic goods reflected not only the strength of the federal government but also an important shift in the notions of legitimate taxation. The internal/external divide no longer represented a limitation on the federal government's taxing power.

5 Not only did the tariff reflect sound fiscal policy, but it was also perceived to be a fair tax. Federal tax policies that accorded equal treatment to all were thought to reflect common notions of fairness. Because the tariff was a tax tied to a commodity, each taxpayer would suffer an identical tax burden, which thus ensured that the federal govern- 
While a tax on commodities, especially foreign commodities, was an accepted method for raising revenue, taxing income remained outside the scope of Congress's power. Because a federal income tax would be tied to income and not commodities, the tax would produce economic burdens that varied from taxpayer to taxpayer. Consequently political theorists viewed the income tax as violating fundamental notions of fairness that called for equal treatment of all citizens (Witte 1985; Ratner 1967; Paul 1954).

In the late 1880s, however, social theorists began to question the prevailing notions of tax fairness that called for taxation of commodities but not income. Reformers involved in the Populist movement criticized the structure of the tariffs and at the same time criticized Congress for failing to adopt federal income tax laws. The Populist critique centered on income inequality and the potential use of the tax laws to equalize the distribution of wealth. Populist reformers took the position that the tariffs and other taxes unfairly forced low-income taxpayers to pay a much higher percentage of their income in tax than high-income taxpayers (Waltman 1985; Ratner 1967; Paul 1954). Thus, the government had adopted a regressive system of taxation that played a role in creating and maintaining the inequality of income between citizens-an outcome that Populists believed was inconsistent with American notions of equality. The correct approach to taxation, it was argued, was to tax income and not commodities. Congress could then implement taxes according to a taxpayer's ability to pay, not according to consumer needs and preferences. The first call for an income tax, therefore, was part of an egalitarian movement that sought to protect the masses from the powerful economic elite.

By 1894, many mainstream Democrats joined in critiquing Congress's use of protective tariffs. The Democrats argued that the tariffs produced indirect economic effects that worked to the advantage of the wealthy industrialists and to the disadvantage of the consumer. The tariffs on imported goods effectively protected local industry from European competitors. With no outside competition and very little local competition, many industrialists achieved great economic success. Indeed, because the tariffs drastically increased the price of imported goods, many American industrialists had a monopoly or an oligopoly which enabled them to charge extremely high prices for their own goods sold in the American market. While the tariffs offered economic protection for the wealthy industrialist, they produced, at the same time, high prices for the consumer (Buenker 1985;

ment did not maintain preferential policies for any taxpayer. Indeed, many argued that the taxes on commodities were fair not only because they accorded equal treatment to all citizens but also because many perceived the taxes to be voluntary; the taxpayer could avoid paying the tax simply by refusing to purchase the commodity. 
King 1983; Ratner 1967). Commentators, therefore, did not question the effectiveness of the tariffs but the fairness of the high prices on consumer goods that the tariffs enabled the businessmen to charge (Waltman 1985; King 1983).

In addition to the perceived unfair impact of the tax structure, congressional leaders feared that if the populace attributed the extreme inequality of income to unfair governmental practices, social unrest would be inevitable. Accordingly, the Democrats supported a federal income tax not only to offset the unfairness of the commodity taxes but also as reform to ease discontent among the poor. Finally, many of the legislators noted that the income tax would be a more efficient method for raising revenue. Unlike the tariffs, many argued that the individual income tax could be raised or lowered without affecting business concerns. Thus, the income tax was perceived not only to be more fair but more efficient.

Although the legitimacy of the federal income tax is now largely unquestioned, in the 1890 s the tax was a radical departure from long-accepted views of the proper scope of the federal government's power. Many commentators and legislators viewed the proposed income tax as violating the most basic tenet of fairness-that the government treat all citizens alike regardless of personal circumstances. Not only would the income tax produce varying affects on citizens based on their level of income, but because the northeastern section of the country had far greater income than the other areas of the country, the federal income tax would produce a geographic bias. Indeed, the income tax seemed so out of line with American values at the time it was proposed, many argued that its advocates were "communists" or "socialists" seeking an "undemocratic" measure that would penalize hard work and ruin the domestic economy (Buenker 1985:11; Witte 1985:71).

Despite this sharp criticism, Congress adopted a federal income tax in 1894 . The new law imposed a $2 \%$ tax only on annual income exceeding $\$ 4,000$ (Ely 1995). Since the average citizen's income was well below $\$ 1,000$, the vast majority would not be subject to the tax (Buenker 1985). The structure of the 1894 income tax, therefore, indicated that Congress was less concerned with yield than it was with economic inequality. By taxing income and not commodities and by only taxing high-income citizens, Congress imposed a progressive tax that would offset the regressivity of the tariffs. While the tariffs were intended to protect American business from European competition, the income tax was intended to offset the income disparity that grew out of the success of the tariffs.

Opponents of the income tax identified the tax as "class legislation" and challenged it as unconstitutional. Finding the Constitution did not give the federal government the power to adopt 
an income tax with sectional or geographic biases, the U.S. Supreme Court in Pollock v. Farmers'Loan E् Trust Co. (1895) declared the tax unconstitutional. The decision sparked a strong public reaction that reflected the divisiveness of the issue. Newspapers around the country reported that the Pollack decision was the final blow to communism, while others complained the Supreme Court had frustrated the popular will of the people (Ely 1995; Paul 1954). In either case, Pollock prevented Congress from using the tax structure to promote economic equality while the taxes intended to promote market growth and productivity were left in place.

Nearly 15 years after the Pollock decision, commentators again called for a federal income tax. Although some argued Congress should reenact the income tax despite the unfavorable Pollock decision, Congress instead proposed an amendment to the Constitution that would explicitly permit an income tax without apportionment among the states. In effect, the Sixteenth Amendment would give the federal government unlimited power to tax. Congress proposed the Sixteenth Amendment to the Constitution in 1909 and by 1913, the states had ratified it and Congress adopted the second peacetime income tax. Like the 1894 tax, the 1913 legislation taxed only high-income taxpayers (Buenker 1985:386).

Unlike the 1894 income tax reform proposed by the Populists, who sought to break the power of the wealthy capitalists, the Progressive tax reformers of 1913 sought to protect the smooth operation of the capitalist system through governmental supervision (Wiebe 1967; Ratner 1967). The Progressives were concerned that the coexistence of great fortunes and complete poverty would produce social unrest and proposed the income tax, in part, to prevent this potential social upheaval. They also saw the income tax as an efficient revenue-raising measure because (1) unlike tariffs, it would not affect business conditions, and (2) it corresponded to citizens' availability of income or their ability to pay.

The 1913 income tax reflected a significant change in tax policy. Taxation could serve not only to promote market growth but also to ensure a fair distribution of income. When the market produced extreme income disparity, the federal government had a role to play in equalizing incomes. But the focus on equality was soon limited by political and economic theorists' greater concern for market growth.

Andrew Mellon, the Secretary of the Treasury throughout the 1920s, was the first to systematically argue that high income tax rates were not consistent with sound fiscal policy and a growing market economy. He cited the tendency of the income tax to divert income to unproductive investment channels, decrease overall investment, and discourage the productivity of high-in- 
come taxpayers (King 1983; Paul 1954). Without explicitly criticizing the redistributive policies that drove the income tax, Mellon managed to brilliantly refocus the debate. The Progressives sought to increase taxes on the wealthy to placate the poor, thereby ensuring that social upheaval would not disrupt the market. Mellon, however, sought to decrease the taxes on the wealthy, thereby avoiding work and investment disincentives that could slow economic growth. By not directly questioning the legitimacy of redistribution, many commentators and scholars committed to income equality could support Mellon's new approach to taxation.

Mellon's strategy was successful. He and a number of other like-minded Republican leaders prompted Congress to lower, but not eliminate, the income taxes throughout the 1920s (Paul 1954). Indeed, Mellon was so persuasive that many Democrats worried that voters would credit the Republicans with boosting the economy. Consequently many Democrats worked with the Republicans on legislation that reduced the level of taxation on high-income taxpayers (King 1983).

When the stock market crashed and the Depression followed, however, Mellon's tax reduction plan was questioned. Many argued that by lowering the federal income taxes and by maintaining high tariffs and excise taxes, Congress had exacerbated the problems associated with income inequality. Indeed, a widely held theory of the Depression's origin focused on income distribution. Many argued that to run efficiently, the economy required mass consumption, but due to the concentration of wealth in a few hands, commentators argued, most people could not afford to consume. Savings could not be reinvested into new industry given people's inability to purchase the output of existing industry. Thus income inequality could lead to production cutbacks, increased unemployment, and further maldistribution of wealth (Rosenof 1983).

Despite this criticism and the rhetoric of the importance of redistribution, tax analysts never completely discarded Mellon's view of taxation. Many historians argue that the revived concern for income equality was largely a political strategy used to calm the masses during the Depression. Support for this position is found in New Deal legislation that raised the taxes of the lowincome taxpayers to a much greater extent than it did those of the high-income taxpayers (Leff 1984; Paul 1954).

This brief historical description demonstrates that the federal tax structure has been used primarily to effectuate economic goals since Congress was given the power to tax in 1787. Congress intended the earliest tariff to protect the American economy from European competition. By the late 1800s, Congress sought to use the tax code to offset the income disparity that grew out of the successful market economy that was, in part, cre- 
ated by the tariff system. Congress adopted the income tax, therefore, with the explicit purpose of burdening the wealthy for the benefit of the poor. By 1920, however, Congress became concerned that the tax itself would disrupt the economy. Theorists argued that Congress should not permit its redistributive policies to circumscribe the growth of the market economy. Accordingly, the taxes adopted to promote economic equality could not be permitted to interfere with economic growth and productivity.

The historical development of the theory explains why tax theorists have failed to accept Simons's argument that Congress should use the federal tax code for the redistribution of income. The approach to taxation he outlined in 1938 was enacted in 1894 but struck down by Pollock in 1895. When Congress again implemented a progressive income tax in 1913, it was subject to immediate criticism for potentially deterring market productivity and investment. By the time Simons wrote in 1938, the view that Congress should use taxation to redistribute income without a concern for the market was soundly defeated. ${ }^{6}$ As time went on, legislators and commentators became even more committed to using the tax code as an instrument for ensuring economic growth. Indeed, Mellon's efficiency-oriented approach has become the prevailing method for determining a "good or bad" tax today. In the next section, I discuss how the market focus in tax policy has shaped our redistributive policies and the effect of these policies on the character of our society.

\section{The Legacy of Tax Theorists' Commitment to the Market Economy}

The commitment to economic growth and tax theorists' corresponding rejection of policies that promote equality without efficiency has contributed to the notion that productive and valuable citizens are those who participate in the market economy. Not only has market participation become the test for productivity but Congress now routinely ties tax benefits to market work and investment rather than to the taxpayer's level of poverty. Indeed, Congress often uses the income tax to provide economic benefits to the wealthy in light of the important role they are perceived to play in the market and to the poor only when they are willing to participate in the market.

6 Scholars seeking to address questions of fairness outside the context of economic issues now have a difficult time addressing one without the other. For example, Jeffrey Schoenblum (1995) has recently addressed the question of whether the progressive income tax is a fair tax. Harkening back to the debates prior to the adoption of the first income tax in 1884, Schoenblum argues that a government committed to equal treatment of all members of the community cannot justify tax burdens that vary with an individual's financial circumstances. Despite Schoenblum's focus on fairness, however, he repeatedly bolsters his argument by referring to notions of economic efficiency. 
The prevailing concern for market growth has not entirely limited tax theorists' concerns for the poor. Tax theorists who argue that the government has an important role to play in providing economic assistance, however, will generally not make the claim that Simons made: income inequality is inappropriate simply because it is "evil" and "unlovely." Instead, legislators and scholars discuss income inequality in the context of Andrew Mellon's market-oriented perspective. The best example of Congress's current use of the tax code to redistribute income to the poor while at the same time promoting productivity can be found in the earned income tax credit provisions (EITC). Congress adopted the EITC to help low-income taxpayers move out of poverty. The EITC does this by providing economic benefits to the poorest taxpayers. Congress does not provide the benefits to all low-income citizens, however but only to those who work in the market. The EITC, therefore, was an effort to create incentives for the poor to work in the market and consequently has found significant bipartisan support (Alstott 1995).

In addition to income inequality, feminist tax scholars have argued that the federal government has a role to play in promoting gender equality and have devised a number of methods that Congress could use to redistribute income to women. The feminist arguments, however, are also often grounded in an efficiency analysis. Professor Edward McCaffery. (1993), for example, has argued that the tax code imposes a number of unfair burdens on women. He points to the joint return provisions, the child-care provisions, and social security taxes to argue that women incur higher costs than men when they enter the waged labor force. The high cost of working in the wage labor market encourages women to undertake a traditional role in the home. McCaffery argues that these market disincentives not only limit women's public roles but also produce inefficiencies in the market due to deadweight losses. ${ }^{7}$ Accordingly, McCaffery argues that Congress should lower married women's marginal tax rate to reduce the inefficient operation of the tax structure. In effect, McCaffery argues the Congress would promote economic efficiency if it redistributed resources to women even if such policy imposed increased costs on men.

Both the EITC and McCaffery's proposal represent important methods for using the code to assist the economically disadvantaged. They also reflect the way in which the efficiency-ori-

7 McCaffery (1993) points out that a tax can produce a deadweight loss when it causes the taxpayer to quit the waged labor market. For example, a taxpayer determines she can afford the costs associated with working (child care, commuting costs, etc.) only if she earns $\$ 5.00$ an hour. If she finds a job that pays $\$ 5.00$ an hour but then finds after tax she will only take home $\$ 4.50$, she will quit. As McCaffery notes, this work disincentive produces deadweight losses because no one gains-the employer, the employee, and the government will all get nothing if the tax pushes the woman out of the market and into the home. 
ented analysis has shaped our notions of productive citizenship. By tying tax benefits only to market participation, the EITC seeks to push the poor into the market. Similarly, McCaffery's proposal to limit the tax on women's wages is also shaped by the desire to provide women with an incentive to move out of the home and into the market.

Attaching economic benefits to market participation is not just one method for redistributing resources, it has come to be viewed as the only legitimate way of redistributing income to the poor. Indeed, many policymakers argue that social welfare programs that are not tied to market participation or waged labor provide resources to the undeserving and unproductive members of our society (see Minow 1994; Pateman 1988).

The market/nonmarket dichotomy has played such an important historical role in the development of tax policy that even Simons, who rejected the market-oriented perspective, could not avoid it. Simons argued that Congress should not include the value of housework into the definition of income. Although tax theorists have rejected the bulk of Simons's work, nearly every theorist examining the value of women's nonmarket labor has agreed with Simons that housework does not produce taxable income. ${ }^{8}$ Although Simons intended this exception to advantage low-income families, his argument has had just the opposite effect. ${ }^{9}$

Simons hoped to relieve low-income women of a burdensome tax by distinguishing between market and nonmarket labor. But more is involved in taxation than just economic burdens. Indeed, it is only by paying employment or payroll taxes that a person becomes entitled to independent social welfare benefits such as social security, medicare, and disability benefits. By taxing only waged labor and not household labor, Congress denies important benefits to women for the work they do in the home. Although women might be entitled to spousal benefits if

8 The one exception is my article, "Taxing Housework" (1996).

9 Simons assumed that defining income to exclude the value of housework would benefit low-income women. He made this assumption based on the fact that high-income families have greater access to resources that in turn enabled them to purchase household services on the market. Simons assumed that low-income families did not have the luxury to make such a purchase. Although this might be true, Simons failed to account for the disparity between low- and high-income women's market participation and the effect market participation has on the level of housework. Data suggest that as women move into the market, their level of housework decreases (Staudt 1996). Because lowincome white women and women of color at all income levels have traditionally worked in the market, they tend to undertake less housework than high-income women. Simons's proposal that Congress leave the value of housework out of the tax base, therefore, has worked to the benefit of high-income women.

Although women's labor market participation was not as great in 1938 as it is today, a significant number of women have always worked in the wage labor force (see Silbaugh forthcoming). A number of recent and forthcoming articles analyze women's labor market participation, the manner in which the Tax Code deters this behavior, and the race and class implications of the tax structure: Brown forthcoming; Fellows 1995; Staudt 1996; McCaffery 1993; for an older study, see Blumberg 1972. 
they are married to a waged laborer, they will not be entitled to benefits based on the value of their own work. If Congress had imposed a tax on all labor regardless of its setting, many women would have far greater economic security in times of old age and disability. Both market and nonmarket labor would have been viewed as equally important and valuable for the operation of the economy. It is not at all clear, therefore, that leaving household services out of the tax base benefits women or low-income families (Staudt 1996).

Simons's argument that Congress should not view the value of housework as taxable income has also perpetuated the notion that the labor (housework) is not productive labor but something more closely associated with leisure. Indeed as Professor Mary Louise Fellows (1995) argues, Simons seems to have made just that point. Fellows points to a portion of Simons's text, in which he set out two hypothetical taxpayers; Mrs. A and Mrs. B. Simons imagined that Mrs. A performs her own housework while Mrs. B hires a maid in order to enjoy bridge and modern fiction (p. 111). Simons noted that both Mrs. A and Mrs. B have obtained similar benefits from their chosen activity, "[ $t]$ he enjoyment of leisure is merely a form of consumption; and the choice between leisure and goods is of the same order as that among economic goods generally" (ibid.).

Simons's hypothetical taxpayers and his analysis of their behavior leave unchallenged the notion that the benefits obtained from bridge, modern fiction, and housecleaning services are identical (Fellows 1995). According to Simons, all three activities produce a similar type of benefit and all are personal in nature. Fellows argues that Simons's analysis linking leisure and housework perpetuated the long-held view that women's household labor was not labor at all but simply a form of leisure. Housework, primarily women's work, therefore, is not seen as productive and important to the economy in the way that many view waged labor in the market.

Indeed, linking housework and leisure together has worked to prevent women's entrance into the market due to the doctrinal distinction between business and personal expenses. Congress permits the deduction of business expenses but not personal expenses. Many commentators have viewed housework, like leisure, as inextricably linked to the taxpayer's personal life. Accordingly, courts and Congress have not permitted women to fully deduct the costs associated with these activities. Many women, however, are unable to work in the waged labor market without paying for child care. Rather than viewing these costs as ordinary and necessary business expenses, courts and legislators have echoed Simons's view of child-care services and have not 
permitted the expenses to be deducted as a business expense. ${ }^{10}$ This economic barrier serves an incentive for women to undertake a traditional household role-a role that is not seen as valuable and productive to the market economy. ${ }^{11}$

Denying full deductibility of child-care expenses harms not only the child-care purchaser but the child-care provider as well. When Congress permits a taxpayer to deduct an expense, the government, in effect, subsidizes a portion of the activity. A deduction for child-care expenses, therefore, would enable women to pay more for child-care services. ${ }^{12}$ Accordingly, nondeductibility maintains the deflated salaries of child-care workers, workers who are primarily low-income women. Fellows (1995) notes that this outcome is particularly problematic not only because lowincome women undertake the work but also because women of color historically have been relegated to these jobs.

Simons's analysis of housework, therefore, furthered the very same notions created by the market-oriented theorists throughout the history of taxation. Both distinguish between market and nonmarket activities, giving value to the latter but not the former. The distinction works to the particular disadvantage of women who undertake the bulk of nonmarket labor. Consequently, women must move into market to become full citizens or they continue at women's work, which is of no value at all for citizenship (Pateman 1988:252).

\section{Conclusion}

Tax theorists historically have focused on market growth and productivity rather than economic fairness in designing the structure of the tax code. Although important developments in taxation were sometimes driven by a concern for fairness, such as the move to an income tax in the late 18th century, the measures intended to promote fairness were soon limited by the greater concern for market growth. That the prevailing view in tax theory has been market-oriented can be seen in Simons's work. Despite being entirely committed to promoting economic equality, Simons could not avoid drawing boundaries for tax purposes be-

10 Congress, however, has permitted women to deduct part of the costs of child care. The amount permitted to be deducted, however, is far less than the actual cost incurred. See Staudt 1996; McCaffery 1993.

11 This market disincentive has been the subject of debate in the tax literature for nearly 20 years. For a discussion of the debate, see Blumberg 1978; McCaffery 1993; Zelenak 1994; Staudt 1996.

12 This phenomenon can be seen in the operation of sec. 163, the provision allowing a deduction for the interest on home mortgages. The deduction has inflated the cost of homes on the market to such an extent that many current homeowners worry about legislators' and commentators' call for the repeal of the deduction. Repealing the deduction would cause housing prices to drop suddenly, thereby putting current homeowners in a position of having purchased homes for much more than the price at which they could sell them. 
tween market and nonmarket activities. Although promoting economic growth is arguably beneficial to all members of society, I argue that by privileging the market, tax theorists promote the notion that the most productive and valuable citizens are those who are successful market participants.

The important question this review essay raises is, Why does tax policy seem to be driven more by a concern for the market than by a concern for fairly distributing the cost of our public goods? Perhaps one reason is that tax theorists' views on fairness widely diverge. The recent debate on the flat tax demonstrates the continuing problems of designing a tax that individuals perceive as fair. Another reason is the disciplinary focus of the tax policy literature. Economists have long contributed to tax policy scholarship, but few political scientists, sociologists, anthropologists, or sociolegal scholars have studied the behavioral aspects of taxation beyond tax compliance. Perhaps this is an area that is particularly ripe for political, sociological, and anthropological study.

\section{References}

Alstott, Anne L. (1995) "The Earned Income Tax Credit and the Limitations of Tax-based Welfare Reform," 108 Harv. Law Rev. 533.

Bailyn, Bernard (1967) The Ideological Origins of the American Revolution. Cambridge: Harvard University Press.

Blumberg, Grace (1972) "Sexism in the Code: A Comparative Study of Income Taxation of Working Wives and Mothers," 21 Buffalo Law Rev. 49.

Brown, Dorothy (forthcoming) "The Marriage Bonus/Penalty in Black and White," in K. Brown \& M. L. Fellows, eds., Taxing America. New York: NYU Press.

Buenker, John D. (1985) The Income Tax and the Progressive Era. New York: Garland Publishing.

Cohen, David (1939) "Book Note: Personal Income Taxation," 87 Univ. of Pennsylvania Law Rev. 256.

Ely, James W., Jr. (1995) The Chief Justiceship of Melville W. Fuller 1880-1910. Columbia: Univ. of South Carolina Press.

Fellows, Mary Louise (1995) "The Myth of Tax Principles: A Case Study on Child Care Expenses." Unpub., Univ. of Minnesota Law School.

Griswold, Erwin N. (1938) "Book Reviews: Personal Income Taxation," 32 Illinois Law Rev. 895.

Hu, Tun Yuan (1950) The Liquor Tax in the United States, 1791-1947: A History of the Internal Revenue Taxes Imposed on Distilled Spirits by the Federal Government. New York: Columbia Univ. Press.

King, Ronald Frederick (1983) "From Redistributive to Hegemonic Logic: The Transformation of American Tax Politics, 1894-1963," 12 Politics $\mathcal{E}$ Society 1.

Klein, William A., \& Joseph Bankman (1994) Federal Income Taxation. Boston: Little, Brown.

Law Journal (1938) "Legal Literature: Personal Income Taxation," 85 Law J. 334.

Leff, Mark H. (1984) The Limits of Symbolic Reform: The New Deal and Taxation, 1933-39. New York: Cambridge Univ. Press. 
McCaffery, Edward J. (1993) "Taxation and the Family: A Fresh Look at Behavioral Gender Biases in the Code," 40 UCLA L. Rev. 983.

McIntyre, Michael, \& Oliver Oldman (1977) "Taxation of the Family in a Comprehensive and Simplified Income Tax," 90 Harv. Law Rev. 1573.

Minow, Martha (1994) "The Welfare of Single Mothers and Their Children," 26 Conn. L. Rev. 817.

New York University Law Quarterly Review (1938) "Book Notices: Personal Income Taxation," 15 New York Univ. Law Q. Rev. 479.

Pateman, Carole (1988) "The Patriarchal Welfare State," in A. Gutman, ed., Democracy and the Welfare State. Princeton, NJ: Princeton Univ. Press.

Paul, Randolph E. (1954) Taxation in the United States. Boston: Little, Brown.

Ratner, Sidney (1967) Taxation and Democracy in America. 1st ed. New York: John Wiley \& Sons.

Rosenof, Theodore (1983) Patterns of Political Economy in America: The Failure to Develop a Democratic Left Synthesis, 1933-1950. New York: Garland Publishing.

Schoenblum, Jeffrey A. (1995) "Tax Fairness or Unfairness? A Consideration of the Philosophical Bases for Unequal Taxation of Individuals," 12 American J. of Tax Policy 221.

Silbaugh, Katharine (forthcoming) "Turning Labor into Love: The Law of Housework," Northwestern Univ. Law Rev.

Staudt, Nancy C. (1996) "Taxing Housework," 84 Georgetown Law J. 1571.

Waltman, Jerold L. (1985) Political Origins of the U.S. Income Tax. Jackson: Univ. Press of Mississippi.

Wiebe, Robert H. (1967) The Search for Order, 1877-1920. New York: Hill \& Wang.

Witte, John F. (1985) The Politics and Development of the Federal Income Tax. Madison: Univ. of Wisconsin Press.

Wueller, Paul H. (1938) "Reviews: Personal Income Taxation," 53 Political Science Q. 428.

Zelenak, Lawrence (1994) "Marriage and the Income Tax," 67 Southern California Law Rev. 339.

\section{Case}

Pollock v. Farmers' Loan \& Trust Co., 157 U.S. 429 (1895), 158 U.S. 601 (1895). 